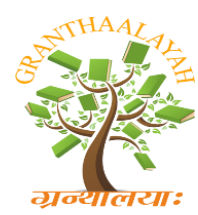

INTERNATIONAL JOURNAL OF RESEARCH GRANTHAALAYAH

A knowledge Repository

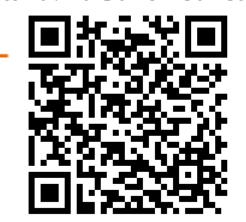

Social

\title{
THE COLONIAL COFFEE COMPULSION MARKETING POLICIES IN KILIMANJARO, TANZANIA
}

\author{
Dr. Somo M.L. Seimu ${ }^{* 1}$ \\ ${ }^{* 1}$ Lecturer, Moshi Co-operative University \\ Postal Address: Moshi Co-operative University, Sokoine Road, P.o.Box 474, Moshi,
} TANZANIA

\begin{abstract}
This is a historical study that utilises primary evidences from Tanzania National Archives (TNA) to examine the compulsion marketing policies imposed by the Tanzania's colonial authority among small-scale native coffee producers in the slopes of Mount Kilimanjaro. The policies were provided under Section 36 of the 1932 co-operative legislation. Also, the 1934 Chagga Rule; and the 1937 Native Coffee (Control and Marketing) Ordinance, which became a key and permanent coffee marketing policy in Tanzania that granted the Moshi Native Coffee Board (MNCB) and KNCU monopoly over the native produced coffee.
\end{abstract}

Keywords:

Kilimanjaro, coffee, marketing, natives, co-operatives, KNCU.

Cite This Article: Dr. Somo M.L. Seimu, "THE COLONIAL COFFEE COMPULSION MARKETING POLICIES IN KILIMANJARO, TANZANIA” International Journal of Research - Granthaalayah, Vol. 4, No. 5 (2016): 139-155.

\section{INTRODUCTION}

\subsection{THE BACKGROUND}

This is a historical paper that examines compulsion marketing policies imposed by the colonial authority among small-scale coffee growers on the slopes of Mount Kilimanjaro in Tanzania. A paper briefly begins by highlighting the early and development of colonial coffee farming and policy among small-scale coffee growers. The encouragement of small-scale coffee growers was primarily geared towards fiscal advantages. ${ }^{1}$

Tanzania which was a German colony before the outbreak of First World War. When the British took over Tanzania (then Tanganyika) in 1919 it immediately began encouraging the small-scale growers into the cash crop economy in an attempt to reconstruction of the economy. Arguably, this was Britain's opportunity to utilise colonial resources for its own economic benefits. ${ }^{2}$ Under Article 3 of the Mandate Agreement Britain responsibility was to safeguard the material well- 
being, native interests and social progress of the Tanzanian population. ${ }^{3}$ Yet, Britain administered Tanzania just like any other colony whereby financial self-sufficiency was emphasised to cover administration costs so as to avoid draining the United Kingdom Treasury. ${ }^{4}$ Self-sufficiency had to be achieved under two important interrelated policies. ${ }^{5}$ First, the development and increase in agricultural production for export; and secondly, encouragement of small-scale growers in cash crop cultivation to provide growers with opportunities for income. ${ }^{6}$ To realise both policies, the small-scale growers had to have access to or ownership of land. Land ownership was provided under the Mandate Agreement, Article $22^{7}$ which was used by small-scale growers to grow cash crops.

\section{MOTIVATION}

Cash crop production and marketing in Africa is extensively documented with emphasis revolves around a general scenario regarding supply and export of foodstuff and raw materials that were in demand in industrial Europe to alleviate shortages. ${ }^{8}$ Despite a significant development and colonial authority commitment in developing coffee in Tanzania there is very limited documentation mainly about native growers on the slopes of Mount Kilimanjaro. And those in existence area marred with disjointed and punctuated that has created a knowledge gap mainly in coffee marketing policies that this paper attempts to fill by specifically examining compulsion marketing policies imposed by the colonial authority among small-scale coffee growers on the slopes of Mount Kilimanjaro in Tanzania.

\section{MATERIALS AND METHODS}

This is a historical study that utilises primary evidences from Tanzania National Archives (TNA) in Dar Es Salaam to examine the compulsion marketing policies. The evidence obtained provides a significant policy first hand evidences. Materials that has been extensively used for this paper includes the colonial government's agriculture Annual Reports, Policies, Memoranda, Orders, meeting minutes and Circulars on agriculture, agricultural marketing and co-operative legislations as well as the Provincial and district reports that dates from 1920s to 1940s.

\section{COFFEE FARMING}

This sections attempt to highlights coffee farming among small scale growers so as to lay a linkage with marketing. A history of coffee farming on the slopes of Mount Kilimanjaro shows that the crop was introduced by Missionaries in 1898 during the German colonial rule. ${ }^{9}$ Coffee production kept on expanding further year after year; and this was partly due to the establishment of coffee plantation owned by the settlers who employed natives as labourers and trained growers in the appropriate cultivation techniques. ${ }^{10}$ The improved coffee farming methods were also employed by the natives that led to the improvement of production in the farms.

However, the development of the crop was disrupted during the First World War when the growers abandoned production it due to lack of market. The settlers most of whom were German fled the country during the war, thus their plantation were abandoned too. However, the Greeks and some Indians planters continued with production. In 1919 the British colonial government began providing support to small-scale coffee growers, mainly WaChagga (the natives on the 
slopes of Mount Kilimanjaro) in an attempt to revive the industry ${ }^{11}$ which was implemented by Sir Charles Cecil Farquharson Dundas ${ }^{12}$ when he was the DC of Moshi (1919 to 1924) ${ }^{13}$ not only for export, but also to enable growers to pay poll tax. ${ }^{14}$

In an effort to revive the industry among the natives, Dundas, accompanied by Joseph Merinyo, an employee in the Administration Department visited and had meetings with growers from $1921 .^{15}$ It was during their visits and meetings the growers became more interested in coffee cultivation. During the visits growers were asked to replace their aging coffee trees. ${ }^{16}$ Joseph Merinyo was responsible for supplying coffee seedlings and was permitted by the DC to start nurseries with a start-up capital at a cost of only 25 rupees. ${ }^{17}$ Seedlings from Merinyo's nurseries which were in Old Moshi with the help of the Chief (Mangi) Abraham of the area were sold to interested growers and Chiefs across the district. ${ }^{18}$ At this juncture, the role played by chiefs was mobilisation and enforcement of coffee farming practices among its subjects. As the demand grew, Merinyo could not cope and chiefs were granted permission by Dundas to start nurseries in their respective areas of jurisdiction. ${ }^{19}$ Dundas' efforts were very successful and highly appreciated by the natives hence, he was honoured as Wasahuye O Wachagga i.e. the elder grandfather of WaChagga. ${ }^{20}$ The encouragement by Dundas from his time when he took office as the DC of Moshi, coupled with the chief's enthusiasm to use their land to grow coffee led to the tremendous and rapid growth of acreage in production. This growth is summarised in Table 1 below.

Table 1: Number of Coffee Growers and Acreage 1923 - 1961 in Kilimanjaro

\begin{tabular}{lll}
\hline Period (June - July) & Number of growers & Acreage \\
\hline $1923 / 24-1927 / 28$ & 5,500 & 2,200 \\
$1928 / 29-1932 / 33$ & 10,700 & 4,500 \\
$1933 / 34-1937 / 38$ & 21,300 & 10,100 \\
$1938 / 39-1942 / 43$ & 26,700 & 15,800 \\
$1943 / 44-1947 / 48$ & 29,800 & 17,900 \\
$1948 / 49-1952 / 53$ & 33,000 & 23,500 \\
$1953 / 54-1957 / 58$ & 39,000 & 29,200 \\
$1958 / 59-1960 / 61$ & 44,800 & 33,700 \\
\hline
\end{tabular}

Source: Compiled from Kilimanjaro Native Planter Association and KNCU reports from 1923 1960

The parallel existence of two competing agricultural sectors split between the European plantation/settlers and African small-scale growers led to tension. ${ }^{21}$ Settler farmers resented the growth of African coffee production and in response they exerted pressure on the colonial administration to rescind the policy because they believed African growers could not be entrusted with the industry due to their inexperience and a lack of technical knowhow. In particular, settlers argued that 'ill-informed growers in the industry would lead to the spread of coffee diseases into their trees'. ${ }^{22}$ European planters attempted to displace the growers from the coffee industry in order to force them to become labourers in their plantations while the native growers struggled to maintain their economic autonomy.

As a result of settler agitations the growers banded together, forming the Kilimanjaro Native Planters Association (KNPA) in 1925 to protect their interest in coffee and the development of 
the industry and to access colonial government support including management provided by the colonial civil servants. ${ }^{23}$ The Association's representatives (wawakilishi) were made responsible for providing practical educational instructions on coffee cultivation, spraying insecticides and pesticides to protect trees from being damaged and infected. ${ }^{24}$

The growing number of coffee growers and acreage in Kilimanjaro was partly the result of the DC, the colonial government policy, the leadership of the KNPA which was formed in 1925 and later Kilimanjaro Native Co-operative Union (KNCU) and its affiliated societies' encouragement since. By 1936 the volume of coffee produced by growers surpassed that of the European planters. ${ }^{25}$ It has to be clear that, such expansion did not necessarily imply opening up new farms or additional land because coffee was often grown on the same farm with a banana trees under the intercropping system.

\section{COFFEE MARKETING}

Coffee marketing in Kilimanjaro from the beginning was briefly under the control of Indians, Greeks, Missionaries and some civil servants. The business was taken over by the KNPA from 1925 and this is when the native growers began to be directly involved in marketing coffee through their organisation. ${ }^{26}$ Consequently, coffee cultivation and marketing was placed under control of Africans and the support from the government was maintained for example in protecting the Association. The involvement of the KNPA in crop purchase was emulated by growers from coffee bulk marketing scheme which was being undertaken by the settler's organisation, the Kilimanjaro Planters Association (KPA). ${ }^{27}$ The association received government technical support that included developing a co-operative marketing scheme to help members sell their produce. ${ }^{28}$ The protection of the Association was provided with effect from April $1^{\text {st }} 1929$, when the colonial authority granted the coffee marketing monopoly under Section 15 of the Native Authority Ordinance No.18 of 1926 that market a beginning of the compulsion coffee marketing policies on the slopes of Mount Kilimanjaro. However, the KNPA was in constant friction with colonial authority. The KNPA leaders challenged some of the colonial policies hence it was viewed as politically suppressive that had to be strangulated through a cooperative legislation that, deprived it access not only to members but also revenues.

\subsection{THE 1932 CO-OPERATIVE LEGISLATION}

In 1932 co-operative legislation was passed leading to the restructuring and replacement of the KNPA by. Under Section 36 of this legislation growers were compelled to be members of a society primarily to deprive the KNPA membership as all growers had under mentioned Section of the legislation to be members of the co-operative societies. The growers were also compelled to sell their produce through co-operatives that deprived KNPA supply of coffee from African growers.

Whereas the legislation was designed to suffocate the KNPA access to coffee produced by natives and controlling coffee through co-operatives; ${ }^{29}$ as a result, the settlers coffee producers were trapped too. ${ }^{30}$ The colonial authority, however, was hesitant to apply the sections as the settlers were also supposed to abide. Instead, in 1934 a new legislation, the Chagga Rule; described by Coulson simply as compulsory marketing order ${ }^{31}$ without establishing its impact on 
the natives produced crops and the agriculture marketing policy as a whole. For example, the Chagga Rule excluded European planters, but compelled the native growers to sell their coffee through the KNCU. It has to be noted here that, the Chagga Rule segregated the natives from non-natives, mainly European planters. ${ }^{32}$ Strickland seems to concur with the idea as he argues that, it was unreasonable to expect these different types of coffee to be bulked and marketed through the same agency. ${ }^{33}$ Under the legislation thy sold their coffee produce through a nonnative only co-operative society, the Tanganyika Coffee Growers Association (TCGA) which was formed in 1935 for this purpose. ${ }^{34}$

When coffee prices fell growers rioted because under the Chagga Rule they were not free to sell their coffee on the open market. In an attempt to quell the riots the government was prompted to pass yet another racially based legislation, the native coffee control Ordinance, No 26 of 1937 which created the government's native coffee control Boards, the Moshi Native Coffee Board (MNCB) in November $1937 .{ }^{35}$ Consequently native coffee cultivation in Kilimanjaro was placed under control of the government. The MNCB's purpose was to advance and improve the cultivation of coffee grown by natives through management of coffee nurseries by instructing growers in methods of planting, cultivation harvesting or preparation and marketing of native coffee. ${ }^{36}$ The MNCB recruited some of wawakilishi to work as extension staff to provide guidance to growers. The government intervention in agriculture production was defined by the function that the marketing board had to play. Clearly, this did not lead to direct government involvement in production. Crop production/cultivation responsibility remained in the hand of growers, but under control of the colonial authority.

The colonial authority established measures to control coffee marketing in Kilimanjaro. The policy was incorporated under section 36 (ii) of the 1932 Co-operative Ordinance, which laid down that if 75 per cent of the producers in an area had to sell through one agent. In principle the mentioned sections formed the bedrock to the cash crop marketing policy in Tanzania. The legislation's section provides also that, non-members of the organization are automatically members of the society and should sell to the organisation or its affiliated societies. It has to be noted that, this section provides for obligatory membership to all growers to a co-operative society contrary International Co-operative Alliance (ICA) and Rochdale voluntary co-operative principles. This clearly suggested a violation of the co-operative principles regardless of the pretext that it was designed to protect growers from unscrupulous traders and intention to develop the native coffee industry. ${ }^{37}$ Moreover, under the Sections, the growers were prohibited to sell their produce at other places than established co-operatives as a result it created marketing monopoly.

Regardless of mentioned flaw, in 1933 KNCU applied from the colonial authority to employ Section 36 (i and ii) of the co-operative legislation. ${ }^{38}$ However, the colonial authority was hesitant to approve its implementation in Kilimanjaro due to the existence of both the settlers mostly Europeans and small-scale Chagga/native growers. The hesitation was obviously due to its impact on European coffee planters who had to sell their produce through the KNCU and its affiliated societies. Separate legislation was the only option to keep European planters safe and immune from the provision. However, implementing separate legislation was a violation of the Order of Mandate that prohibited racial segregation. ${ }^{39}$ For the Tanzanian colonial authority and particularly Strickland to have members comprising of different races and different types of 
coffee to be bulked and marketed through the same agency. ${ }^{40}$ Obviously, this was impractical as he indicates to everyone throughout the world that, the provision in undisputable and the emphasis was, not only who produces; but also, what is produced should be separated based on race. $^{41}$

In an attempt to get over such defect in the co-operative ordinance, the government had to bring forward a specific section for the WaChagga growers. It was decided that an ordinance, the Coffee (Moshi District) Rules popularly referred as the Chagga Rule (or masharti in Kiswahili) should be made under section 15 of the Native Authority (NA) Ordinance. ${ }^{42}$ Accordingly, the Chagga Rules were drafted in August 1934 and passed on October $1^{\text {st }}, 1934$ by the Chagga Council to compel native growers to sell coffee through the KNCU.

It has to be noted here that, the idea originated with the colonial government. However, the Chagga Council which was a Native Authority (NA) was persuaded by the colonial government to pass it. This demonstrates an attempt by the colonial government to delegate powers for promulgation of native legislations in accordance to the Indirect Rule policy primarily on the pretext of protecting the native coffee growers. In reality it was intended to protect the European settlers from being compelled to market their produce to the co-operative societies, the memberships of which were predominately natives. The policy was justified by the colonial authority as a necessary measure that;

No satisfactory marketing arrangements can be made until every native grower is compelled to sell his coffee through the Association as this would eliminate the local buyers from competing with the Association. It also ensures that the association remained in existence. ${ }^{43}$

It is obvious that, engagement of the NA was to keep the colonial authority from being implicated with racial policies which went against the Mandate policy. The Chagga Rule was rooted in racial segregation policy and compelled native growers only to marketing the coffee to the co-operatives. All in all, the colonial authority was responsible for creating racial barriers by pressuring to the NA to promulgate the legislation. In this view, the NA and Chiefs found themselves embroiled in the affairs of growers and societies without their participation.

The employment of the Rule coincided with the collapse of the coffee price in the world market in which Kilimanjaro especially the Wachagga coffee was not spared. Table 13 below shows a decline and decrease of coffee paid to growers. In 1934/35 coffee season suffered a drastic fall of coffee price in the world market triggered by the flooding in the market of the produce from Brazil. ${ }^{44}$ Table 2 below shows a decline and increase of coffee price paid to growers.

Table 2: Coffee Production and Amount Paid to the KNCU (1932 - 1946)

\begin{tabular}{llllll}
\hline Season & $\begin{array}{l}\text { Coffee crop parchment } \\
\text { (in tons) }\end{array}$ & $\begin{array}{l}\text { Total amount paid } \\
\text { in } £ \text { to growers }\end{array}$ & $\begin{array}{l}\text { Price per lb. paid to } \\
\text { growers }\end{array}$ & town \\
\hline $1932 / 33$ & 1,072 & 35,426 & 29.55 & \\
$1933 / 34$ & 1,167 & 35,384 & 27.03 & \\
$1934 / 35$ & 1,587 & 35,456 & 19.85 & \\
$1935 / 36$ & 1,684 & 33,995 & 16.94 & \\
$1936 / 37$ & 882 & 18,707 & 18.95 & \\
$1937 / 38$ & 1,472 & 33,336 & 20.16 & \\
\hline
\end{tabular}




\begin{tabular}{llll}
\hline $1938 / 39$ & 1,959 & 58,747 & 26.78 \\
$1939 / 40$ & 2,680 & 72,275 & 24.17 \\
$1940 / 41$ & 4,063 & 84,798 & 18.53 \\
$1941 / 42$ & 1,948 & 52,184 & 23.97 \\
$1942 / 43$ & 3,103 & 145,399 & 41.96 \\
$1943 / 44$ & 2,114 & 131,012 & 57.49 \\
$1944 / 45$ & 3,974 & 276,380 & 62.96 \\
$1945 / 46$ & 3.102 & 173,032 & 49.81 \\
Total & $\mathbf{3 0 , 8 0 7}$ & $\mathbf{1 , 1 8 6 , 1 3 1}$ & \\
\hline
\end{tabular}

Source: Moshi District Book I 1939/40 to 1943/44 and the KNCU 1946/47 Annual Report, Appendix B

Table 2 above shows payment trends in which 1934/35 season advances paid were only -/16 cents per lb. (pound) of parchment coffee delivered. ${ }^{45}$ It shows a sharp fall in 1935. The crisis was so serious that the KNCU could not pay growers a second instalment ('mabaki' in Kiswahili). The KNCU issued a communiqué through the KNCU's Monthly bulletin, the Uremi on $22^{\text {nd }}$ August 1935 of the members on impending problem that could not sell most of coffee in London market. ${ }^{46}$ However, the message did not show why coffee could not fetch a buyer and the reason for the fall of prices. However, the growers showed trust in the KNCU and there was not reaction from them. At the same time the KNCU had to embark upon measures to resolve financial problems to meet its commitments to pay growers in 1934/35 season.

On the other hand, the settlers, especially of German origin, were not affected by the crisis since they exported their coffee directly to German and fetched a higher price that was fully paid in cash. At the same time there were several traders, mostly Asian, German and British settlers, missionaries and traders paid better prices than the Union. For example, the KNCU paid 15 cents per a lb. While such companies as Sheriff Jiwa paid 20 cents and H. Bueb paid 21 to 25 cents, depending on the quality of the delivered coffee. ${ }^{47}$ The German settlers offered between 10 and 15 per cent above the market price on condition that part of the payment was spent to purchase agricultural implements that they were selling ${ }^{48}$ and exported coffee to Germany. ${ }^{49}$ In this effect, the growers demanded to sell coffee wherever and to anyone provided s/he is ready to pay them well and promptly. ${ }^{50}$

Therefore, growers could not see the KNCU justification for paying them low prices. For them, they felt that they were being cheated. This generated criticism and by November 1936 growers/members had lost patience and pressed for implementation of various alternatives to resolve the problem; ${ }^{51}$ first, that they pull out of the KNCU for open market alternative where they could fetch better price; and secondly, removal of societies leaders from office for failure to defend their interests and welfare in the Union forums. The societies in question were Machame Central and East, Marangu Central and East but the members alternatives were dismissed by the KNCU because they were contrary to the Chagga Rule. ${ }^{52}$ The permission was briefly granted by the end of 1935 but was cancelled before a start of 1937 coffee marketing season. ${ }^{53}$ This fuelled further discontent and dissatisfaction amongst the WaChagga coffee growers. It was pointed out that discontent was widespread over the whole mountainside engineered by some individuals; ${ }^{54}$ but more so in Machame Central and East and Marangu East societies that composed of about 3,784 members in all and owned 24 per cent of the total crop produced in Kilimanjaro. ${ }^{55}$ On September $15^{\text {th }} 1937$ riots broke out in these societies. Between September 16 to $17^{\text {th }} 1937$ there 
was riots in Marangu East, where growers replaced existing leaders with members who 'refused to recognise the existing by-laws'. ${ }^{56}$

The riots popularly referred to by growers as 'Coffee Riots' also occurred in 27 other primary societies in Lyamungo, Masama, and Machame North. During the riots the primary society's stores were ransacked. ${ }^{57}$ The rioters complained that owing to heavy overhead expenses the Union paid lower prices than they could obtain outside. ${ }^{58}$ The Chiefs were also accused by growers of conspiring in the passage of the Chagga Rule; therefore the Chiefs were viewed as being against their economic interests and welfare.

The government restored order by drafting in the police and air force. ${ }^{59}$ Around 70 rioters were apprehended and sentenced to jail. ${ }^{60}$ Some of the ring leaders were imprisoned and about 14 others were deported to Singida, Iringa and Sumbawanga in the Southern highlands of Tanzania. ${ }^{61}$ The KNCU also suspended sending money to all societies where riots had taken place. $^{62}$ These actions were intended to ensure that growers accepted the coffee price paid by KNCU regardless of how low it was. These measures to reinforce Section 36 of the 1932 cooperative legislation sought to secure the loyalty of members of co-operative movement through force.

Other societies disaffiliated from the KNCU over its failure to meet its obligations. ${ }^{63}$ This created an impasse that forced the PC and Moshi's DC to intervene. The PC had meetings in Marangu and Machame which successfully ended by restoration of societies' committees. ${ }^{64}$ In 1939 efforts were initiated by the Moshi District officer, Mr Bruce Hunt for reorganisation of such societies and get them back to the KNCU framework. In one instance the DO wrote ${ }^{65}$ to Mangi Addiel Solomon of Mwika asking him to facilitate the exercise for West Mwika Primary Co-operative Society which was in his Chiefdom.

It was viewed by the colonial administrators however that, the riots were politically motivated because of a number of the German settlers, about 882 in total for the whole district and Missionaries in the area. ${ }^{66}$ The accusation against the traders illustrates the belief that the growers were too ignorant to protest and on the same premise were expected to be obedient to the Chagga Rule. In an investigation of the causes of the riots it was reported by the Registrar of Co-operative Societies, Mr. R.C Northcote, that they were instigated by the agitators, mostly Asian traders as well as German settlers, Greeks, teachers and missionaries ${ }^{67}$ who exploited the poor price paid by the KNCU as an avenue for them to accumulate coffee.

Additionally, Northcote's accusations about the riots have been linked to Germany's campaigns for the return of some of her colonies which were mentioned by Hitler in conversations with Sir John Simon on March 25, 1935. At the same time Germany was lobbying victor power to be considered for membership in the League of Nations so that it could qualify to administer colonies. However, Britain rejected Germany's proposal, as by returning its former colonies Britain would have been sacrificing sources of raw materials and foodstuff supply to a potential enemy. ${ }^{68}$ Lord Winster in his speech to the House of Lords misleadingly asserted that one of the reasons for the riots was the failure to educate the members of the Union in co-operative principles, ${ }^{69}$ which led members to refuse to adhere to the society by-laws. ${ }^{70}$ The KNCU reacted 
by suspending such societies and suspended coffee payments, advances though the Chagga Rule was applicable. $^{71}$

In a communique the DC informed and ordered the members to re-join the society which was the only option available for them to sell their 1939 produce. $^{72}$ This was clear government interference and an obvious compulsion that became a dominant factor. It was stressed that its only if a society affiliated back to the Union could they sell produce in accordance to the law. This message was communicated through a memo read aloud by the Mangi at a growers meeting held on July $1^{\text {st }} 1939$.

At the meeting the Mangi managed to convince his subjects convinced and it was decided to elect new leadership 'dedicated' and committed to comply with the KNCU by laws. Marua bin Kishimbo was elected as Chairperson, Abel bin Maktano, the vice-Chairperson and Yohanne bin Manaseh as Secretary. ${ }^{73}$ To this effect Mangi asked the DO to restore West Mwika Primary Cooperative Society into the list of the KNCU affiliated societies; and asked for permission for that case to have the society's office opened for business to serve his subjects. A decision to elect new faces by rejecting the old ones to take society's office was translated by Mangi Abdiel Solomon as a significant step towards restoration of confidence in the Union ${ }^{74}$ at a point where growers had lost trust on it.

\subsection{THE 1937 NATIVE COFFEE (CONTROL AND MARKETING) ORDINANCE}

As a result of the riots the government decided to alter how it exercised control over the native coffee industry. In October 1937 the Native Coffee (Control and Marketing) Ordinance No 26 was passed to replace the Chagga Rule. The Ordinance provided for the control of the native coffee industry and compulsory marketing of the produce, but it did not compel growers to sell their produce through a specific organisation. Promulgation of a new policy can, therefore, be viewed as a victory for the growers. But it was embarrassing to Chiefs and central government when the Chagga Rule was revoked by the Governor on December $21^{\text {st, }} 1937$ in response to the recommendation made by a committee that was formed to investigate the crisis/riots that faced the $\mathrm{KNCU}^{75}$

Nevertheless, the legislation did not make a significant departure from the Chagga Rule as it restricted growers from selling coffee to the open market. The important contrast with the Chagga Rule in the Native Coffee Ordinance was that did not specify to which organization the growers were compelled to sell their produce, but only mentioned an agency that the Board may suggest. In Moshi the KNCU was recommended. KNCU maintained its monopoly over native produced coffee because it was the only coffee marketing organization in Moshi due to the Chagga Rule. This provided an indirect integration of the co-operatives into marketing policy. Similarly, no organisation apart from the KNCU and affiliated societies was allowed to operate coffee marketing in the district.

The legislation targeted Native coffee growers and ensured that European growers were not compelled to sell their produce through the KNCU and its affiliated societies. Thus, the native coffee industry was one that was brought under more direct control than that attainable by Cooperative Societies Ordinance Section 36 (i), which required the compulsory sale of produce 
through a registered society. The Ordinance led to the formation of the MNCB, in which under Section 6 all producers of native coffee in the Moshi District were compelled to sell coffee produce to the agency chosen by the Board.

Under the native coffee (control and Marketing) legislations the MNCB became a sole buyer of native produced coffee and it was empowered to appoint an agent/s. As a result, legal ground was provided for application of section 6 that appointed the KNCU as the agent of the MNCB which was set up in November $20^{\text {th }} 1937 .{ }^{76}$ Under the monopoly system provided under the legislation growers had no choice or alternative sell their produce other than co-operatives. Clearly, upon appointment of the KNCU by the MNCB it was integrated into the government marketing machinery. This illustrates that, the KNCU was created and organised by the government so that to facilitate coffee handling and marketing under legal protection. Thus, this does not imply KNCU was an independent business entity, but became the government facilitating machinery for handling the coffee produced by the native growers.

This clearly demonstrates that the co-operative legislation violated the voluntary co-operative principles. However, it was justified by the colonial authority as necessary measure that, "no satisfactory marketing arrangements can be made until every native grower is compelled to sell his coffee through the Association. ${ }^{77}$ A compulsion measure was pursued by the government on view that the members would remain loyal due to the KNPA and later KNCU's efforts to defend growers from coffee growing suppression attempts by the settlers, but the introduction of the policy was ill timed as it coincided with coffee prices plummeting.

A three tier marketing system was established whereby primary societies were at the bottom, $\mathrm{KNCU}$ in the middle and the MNCB at the top of the structure. Under the system primary societies collected the produce from growers and sold it to the KNCU which forwarded them to the Board. This was applauded by the Agriculture Secretariat, who pointed out that 'the MNCB now has a weapon to use'. ${ }^{78}$ This illustrates the colonial authority had meant for the economic subjugation of the growers. It was also pointed out that the Chagga Rule was an embarrassment as it had placed the NAs on the same footing as the Department of State. ${ }^{79}$ The establishment of the MNCB rendered the Chagga Rule inoperative.

The replacement of the Chagga Rule was considered as a decisive step in restoring growers' confidence in Chiefs and the NA and thereafter no immediate challenge to their authority arose. This could be explained by the intimidation growers experienced when the government intervened to quell the riots. Of course, although the legislation replaced the Chagga Rule it strengthened government's grip over the KNCU, and ultimately the affiliated societies and growers through the MNCB. The control of marketing by the Boards implied that co-operatives were denied the necessary independence to operate as member controlled organisations that became a dominant and a permanent feature in agricultural marketing in Tanzania throughout colonial era.

To avoid future unrest the growers were kept well informed by Provincial officials, especially, the Provincial Commissioner (PC), Mr C.F. Hallier, about this new development and the appointment of the KNCU as MNCB's agent. ${ }^{80}$ Such information was communicated to growers in public meetings and articles in Uremi. This announcement was met with great satisfaction by growers because it was interpreted as a sign that the government was ready to listen and 
implement their concerns. Chiefs were equally pleased as they had long been conscious of the anomaly of their positions as sponsor of the Rule which brought them into conflict with their subjects. ${ }^{81}$ Due to meetings and Uremi publication of articles the PC concluded that 'the withdrawal of the Chagga Rule and its replacement by the MNCB are fully and widely understood in Kilimanjaro'. 82

Coincidentally, the setting up of the statutory board, the MNCB came at a time when the coffee price was improving and generated and restored confidence of both co-operatives and the board to growers (see Table 2 above). It was the view of the government officials that such development was met with great satisfaction since it was seen as protection of growers' interest as well as of their organization by the government. ${ }^{83}$

\subsection{THE DEFENCE ORDINANCE AND ORDERS}

Moreover, following the outbreak of the Second World War in 1939, all British colonies were required to ensure they supply coffee to Britain through the British's Ministry of Food. ${ }^{84}$ A supply of commodities had to be placed under the government so as to ensure supply stability, control prices and keep racketeers abay. The supply of commodities from colonies was provided under a long-term contracts. In Tanzania the supply of commodities were embedded under the Emergency Defence Ordinance and Orders of 1939, 1940 and 1943. The Emergency Defence Ordinance and Orders reinforced existing coffee compulsion marketing policies further; and brought native produced coffee marketing and additional control of the British's Ministry of Food.

The Defence Ordinance and Orders reinforced further the control and compulsion marketing of the existing coffee produced by natives. In this, both Emergency and coffee compulsion marketing policies were both implemented simultaneously under which the marketing boards and co-operative societies were charged with handling or purchase fixed quantities of coffee from growers in Kilimanjaro. A price for the supply was determined by the buyer in London which was of course, low so as to ensure that consumers in Britain have access to cheap coffee. However, prices were reviewed on a year-to-year basis ${ }^{85}$ as per Section 7 of the contract. ${ }^{86}$ Under clause 14 of the long-term contract, price could be revised in the view when sterling pound is devaluated. ${ }^{87}$ Again, the Ministry of Food was prepared to pay only two thirds of the free market price during the $1951 / 52$ season. $^{88}$

Under the contract the MNCB supplied coffee between 1940 and 1952 to the Ministry of Food. In that effect, the KNCU became an agent for the Ministry of Food during this period and was required to supply 4,000 tons annually fixed at between 80/- and 105/- shillings each. ${ }^{89}$ Against the backdrop, a loss was inflicted to growers who were paid 80 per cent of the freight on board (fob) value of their coffee following a number of deduction expenses that includes, taxes and levies. ${ }^{90}$

In 1951 the Defence Orders were revoked as they were deemed no longer necessary. ${ }^{91}$ It has to be recalled that, during the time compulsion policies that provided for a relaxation export and price control $^{92}$ and setting up of auctions in Moshi in 1953 where KNCU coffee was sold. All these developments took place when Conservative government took power in $1951 .{ }^{93}$ The 
Conservative policy was against restrictive Labour Party's policies, including rationing. ${ }^{94}$ It championed a reduction in state intervention in the economy in Britain.

It has to be noted however that, the end of both the Emergency and Defence Orders did not bring any change as far as the coffee compulsion marketing policies are concerned. A reduction in state intervention in the economy in Tanzania was not the case as compulsion marketing policies which were brought in effect under the 1937 native coffee control and marketing remained in place not only during colonial period but also until 1990s. ${ }^{95}$ Against the backdrop, the policy was maintained through independence era until 1990s when agricultural marketing policy was liberalised. After 1951 the MNCB monopoly over the handling and export of coffee produced by the native remained in force despite establishment of coffee auction in Moshi. ${ }^{96}$ The KNCU and its affiliated societies were remained as the MNCB coffee handling agents. The MNCB became a sole colonial authority's organisation that fixed native coffee produced prices. In this regard, the co-operative societies in Kilimanjaro became part of the government machinery for organising the compulsion marketing of native produced coffee.

\section{CONCLUSION}

This paper has shown some concerted efforts to rejuvenate coffee industry in the slopes of Mount Kilimanjaro as part of the colonial authority's drive to attain financial self-sufficiency. Agricultural production policies and implementation went hand in hand with the consolidation of marketing through the compulsion legislations under which the growers had to sell their coffee through the agency (societies) appointed by the Board, a feature that dominated for decades. The post-riots era and legislation saw the colonial authority being directly involved through the MNCB in which those who did not adhere were liable to penalty or imprisonment or both under the Native Coffee Ordinance of 1937. Under the legislation the marketing and control boards was formed that established the colonial hegemony over small scale native coffee growers and provided the basis for the government to extract surplus from coffee marketing. Under the legislation, the boards were granted the monopoly over the handling and export of coffee produced by the native and the co-operative societies in Kilimanjaro. In this regard, the cooperative movement became part of the government machinery for organising the compulsion marketing of native produced coffee. Under the policy the autonomous foundation for the cooperative movement's bargaining role was undermined as the co-operatives became the agents of the marketing boards that created suppressive, exploitative and compulsion economic relationship that is further explored in next papers on Tanzania's coffee and cotton bulk purchase during and post-second world war as well as post-war co-operative development.

\section{REFERENCES}

${ }^{1}$ Seimu, S.M.L, The Growth and Development of the Coffee and Cotton Marketing Co-operative Movement in Tanzania, 1932-1982, Unpublished PhD Thesis, University of Central Lancashire, 2015.

${ }^{2}$ L.Hadden-Guest, The Labour Party and the Empire (London, 1926), p13, pp. 83-90.

${ }^{3}$ Billy Frank, (2002), p.16; Alan Pim, (1946), p.155.

${ }^{4}$ Extract from minutes of meeting of the Directors of Agriculture for East African countries (Kenya, Tanganyika and Uganda, held in Nairobi in June 12 ${ }^{\text {th }}$ 1946, TNA 26054; Billy Frank, 
(2002), p.16; Seimu, S.M.L, The Growth and Development of the Coffee and Cotton Marketing Co-operative Movement in Tanzania, 1932-1982, Unpublished PhD Thesis, University of Central Lancashire, 2015.

${ }^{5}$ Melville J. Herskovits, (1952), p. 219; Michael Havinden and David Meredith, (1993), pp. 299 -301; Billy Frank, (2002), p.16; Seimu, S.M.L, The Growth and Development of the Coffee and Cotton Marketing Co-operative Movement in Tanzania, 1932-1982, Unpublished PhD Thesis, University of Central Lancashire, 2015.

${ }^{6}$ Seimu, S.M.L, The Growth and Development of the Coffee and Cotton Marketing Co-operative Movement in Tanzania, 1932-1982, Unpublished PhD Thesis, University of Central Lancashire, 2015.

${ }^{7}$ Permanent Mandates Commission, Minutes, $3^{\text {rd }}$ Session, 1922, p. 280.

${ }^{8}$ Alan Pim, Colonial Agricultural Production: The Contribution Made by Native Peasants and by Foreign Enterprise, (London: Oxford University Press, 1946), pp. 159-160; Andrew Coulson, (1982); Göran Hydén, Beyond Ujamaa in Tanzani: Underdevelopment and an Uncaptured Peasantry, (London: Heinemann, 1980); Philip Curtin, 'The Colonial Economy', In Philip Curtin, Steven Feierman, Leonard Thompson, Jan Vansina, African History: From Earliest Times to Independence, (London: Longman, 1995), pp.446-464; Maxwell Owusu, Agriculture and Rural Development since 1935, In Ali Mazrui (ed.) Africa Since 1935, (Oxford: James Currey Ltd., 1999); J. Tosh 'The Cash Crop Revolution in Tropical Africa: An Agricultural Reappraisal', African Affairs, 79, (1980); W.E.F Ward and L.W. White, East Africa: A century of Change 1870 - 1970, (London: George Allen and Unwin Ltd, 1971); Michael Havinden and David Meredith, (1993); David Sunderland, Managing British Colonial and PostColonial Development: The Crown Agents, 1914-1974 (Woodbridge: The Boydell Press, 2007); N.R. Fuggles-Couchman, Agriculture Change in Tanganyika: 1945 - 1960, (Stanford, California: Food Research Institute, Stanford University, 1964).

${ }^{9}$ Dundas to CS June 1924, TNA 3864/2; Heinrich Brode, British and German East Africa, Their Economic and Commercial Relations, (London: Edward and Arnold, 1911), p.100.

${ }^{10}$ Dundas to the Chief Secretary June 1924, TNA3864/2; DC to PC Ref. No. 23/13, April $21^{\text {st }}$ 1936, TNA 26207.

${ }^{11}$ Pennington Report, TNA13060, p.4

12 Charles Dundas was the Secretary for Native Affairs from 1925 to 1929. In 1929 was appointed as Governor for the Bahamas.

${ }^{13}$ Coffee Ordinance and Regulations Attitude of the KNPA, TNA, 13060; R.J. M. Swynnerton, A .L. B. Bennett and H.B. Stent, All About KNCU Coffee, (Moshi: KNCU, 1948), p.4; John Illife, A Modern History of Tanganyika,(Cambridge: Cambridge University Press, 1979),p.154.

${ }^{14}$ Dundas to the Chief Secretary June 1924, TNA3864/2; DC to PC Ref. No. 23/13 of April $21^{\text {st }}$ 1936, TNA 26207.

${ }^{15}$ Pennington Report, TNA13060,p.4

${ }^{16}$ Seimu, S.M.L, The Growth and Development of the Coffee and Cotton Marketing Co-operative Movement in Tanzania, 1932-1982, Unpublished PhD Thesis, University of Central Lancashire, 2015.

${ }^{17}$ Coffee Ordinance and Regulations Attitude of the KNPA, TNA 13060; (German and Indian Rupee was a currency in circulation until 1925 when the conversion of circulating rupees was 
completed and replacement by florins and shillings currencies which was carried out by the British colonial power East Africa Currency Board.

${ }^{18}$ Dundas to the Chief Secretary June 1924, TNA3864/2; DC to PC Ref. No. 23/13 of April $21^{\text {st }}$ 1936, TNA 26207.

${ }^{19}$ Dundas to CS June 1924, TNA 3864/2.

${ }^{20}$ Charles Dundas, Africa at Crossroads, (London: Greenwood Press, 1955), p.125.

${ }^{21}$ Seimu, S.M.L, The Growth and Development of the Coffee and Cotton Marketing Co-operative Movement in Tanzania, 1932-1982, Unpublished PhD Thesis, University of Central Lancashire, 2015.

${ }^{22}$ Pennington Report, TNA13060,p.4

${ }^{23}$ Seimu, S.M.L, The Growth and Development of the Coffee and Cotton Marketing Co-operative Movement in Tanzania, 1932-1982, Unpublished PhD Thesis, University of Central Lancashire, 2015.

${ }^{24}$ Seimu, S.M.L, The Growth and Development of the Coffee and Cotton Marketing Co-operative Movement in Tanzania, 1932-1982, Unpublished PhD Thesis, University of Central Lancashire, 2015.

${ }^{25}$ DC to PC Ref No 23/13 of April 21 1936, TNA 26207.

26 Session a Paper No. 4, 1937, p.9; KNCU School Lyamungo, TNA 5/375C 24/13; Memorandum of Disturbances in the Moshi District, pp. 208 - 209, TNA 25400; Government of Tanganyika, Annual Report, Northern Province. (Dar Es Salaam: Government Printer, 1937), pp. 9 - 10 .

${ }^{27}$ Seimu, S.M.L, The Growth and Development of the Coffee and Cotton Marketing Co-operative Movement in Tanzania, 1932-1982, Unpublished PhD Thesis, University of Central Lancashire, 2015.

${ }^{28}$ The History of the KNPA, TNA 13060.

${ }^{29}$ Seimu, S.M.L, The Growth and Development of the Coffee and Cotton Marketing Co-operative Movement in Tanzania, 1932-1982, Unpublished PhD Thesis, University of Central Lancashire, 2015.

${ }^{30}$ Seimu, S.M.L, The Growth and Development of the Coffee and Cotton Marketing Co-operative Movement in Tanzania, 1932-1982, Unpublished PhD Thesis, University of Central Lancashire, 2015.

${ }^{31}$ Andrew Coulson, (1982), p. 62.

${ }^{32}$ Seimu, S.M.L, The Growth and Development of the Coffee and Cotton Marketing Co-operative Movement in Tanzania, 1932-1982, Unpublished PhD Thesis, University of Central Lancashire, 2015.

${ }^{33}$ C.F. Strickland, Co-operation in the Colonies, (George Allen and Unwin Ltd., 1945), p.78.

${ }^{34}$ Tanganyika Coffee Board Meeting, Agenda and Minutes, TNA 24304.

${ }^{35}$ Seimu, S.M.L, The Growth and Development of the Coffee and Cotton Marketing Co-operative Movement in Tanzania, 1932-1982, Unpublished PhD Thesis, University of Central Lancashire, 2015.

36 TNA 24/13 KNCU School (Lyamungo), from MNCB to the Secretariat Members of Agricultural and Natural Resource, Ref. No. 75/273, February $20^{\text {th }} 1954$

${ }^{37}$ Seimu, S.M.L, The Growth and Development of the Coffee and Cotton Marketing Co-operative Movement in Tanzania, 1932-1982, Unpublished PhD Thesis, University of Central Lancashire, 2015. 
${ }^{38}$ KNCS to Chief Secretary in April $22^{\text {rd }} 1932$ signed by Joseph Maliti (President), Stepano Lema (Secretary) and A.B. Bennett (Manager), TNA 20378.

${ }^{39}$ Extract from Lord Winster in his speech March 1, 2 or 3 to the House of Lords, TNA 357883.

${ }^{40}$ C.F. Strickland, (1945), p.78.

${ }^{41}$ Seimu, S.M.L, The Growth and Development of the Coffee and Cotton Marketing Co-operative Movement in Tanzania, 1932-1982, Unpublished PhD Thesis, University of Central Lancashire, 2015.

${ }^{42}$ Legislation on Control Native Agriculture and Industry, History of the Chagga Rule, TNA 25038.

${ }^{43}$ Report on the Reorganisation of the KNPA, TNA 13060.

${ }^{44}$ T.S. Jervis, 'Marketing of Coffee' in the East Africa Agricultural Journal, May 1957, pp.459464, in Bukoba District Book.

${ }^{45}$ Uremi, August, $22^{\text {nd }} 1935$.

${ }^{46}$ Uremi on $22^{\text {nd }}$ August 1935.

${ }^{47}$ Coffee Ordinance and Regulations Attitude of the KNPA: History of the KNPA, TNA 13060.

${ }^{48}$ Lord Hailey, An African Survey: A study of Problems Arising in Africa South of Sahara, (London: Oxford University Press, 1938), pp.1472 -1473.

${ }^{49}$ W.K.H Campbell, Practical Co-operation in Asian and Africa, (Cambridge: W. Heffer and Sons ltd., 1951), p. 196.

${ }^{50}$ Lord Hailey, An African Survey: A study of Problems Arising in Africa South of Sahara, (London: Oxford University Press, 1938), pp.1472 -1473.

${ }^{51}$ Seimu, S.M.L, The Growth and Development of the Coffee and Cotton Marketing Co-operative Movement in Tanzania, 1932-1982, Unpublished PhD Thesis, University of Central Lancashire, 2015.

${ }^{52}$ Bennett to Chief Shangali of Machame and Marrealle of Marangu, Folio 34, TNA 5/243.

${ }^{53}$ Tanganyika Territory, LEGCO, A report on the Kilimanjaro Native Co-operative Union, (Dar Es Salaam, Government Printer, 1937), p.9 TNA 19005.

${ }^{54}$ Tanganyika Territory, LEGCO, A report on the Kilimanjaro Native Co-operative Union, (Dar Es Salaam, Government Printer, 1937), a speech to the Registrar of Co-operative Societies from the President of the KNCU, Appendix J, p.59, TNA 19005.

${ }^{55}$ Tanganyika Territory, LEGCO, A report on the Kilimanjaro Native Co-operative Union, (Dar Es Salaam, Government Printer, 1937), p.9, TNA 19005.

${ }^{56}$ Tanganyika Territory, LEGCO, A report on the Kilimanjaro Native Co-operative Union, (Dar Es Salaam, Government Printer, 1937), p.9, TNA 19005.

${ }^{57}$ Tanganyika Territory, LEGCO, A report on the Kilimanjaro Native Co-operative Union, (Dar Es Salaam, Government Printer, 1937), p.9

${ }^{58}$ Lord Hailey, An African Survey: A study of Problems Arising in Africa South of Sahara, (London: Oxford University Press, 1938), p.1472.

${ }^{59}$ Interview with Edwin Mtei, March $20^{\text {th }} 2014$.

${ }^{60}$ PC, Northern Province to CS, Re. No. 377/7/180, November 10 ${ }^{\text {th }}$ 1941, MNCB Vol.II, TNA 255442; Disturbances at Moshi in Connection to KNCU, TNA 25400.

${ }^{61}$ Report to the League of Nations on Tanganyika Territory, 1937, TNA 5/243 pp. 206-13; PC, Northern Province to CS, Ref. No. 25442/30 December 22 ${ }^{\text {nd }}$ 1937, TNA 25442.

${ }^{62}$ Tanganyika Territory LEGCO, A Report on the KNCU, (Dar Es Sa salaam: Government Printer, 1937), p. 9 TNA 19005. 
${ }^{63}$ Government of Tanganyika, Annual Report, Northern Province. (Dar Es Salaam: Government Printer, 1937), p. 40.

${ }^{64}$ Tanganyika Territory LEGCO, A Report on the KNCU, (Dar Es Sa salaam: Government Printer, 1937), p. 9 TNA 19005.

${ }^{65}$ DO to Mangi of Mwika Abdiel Solomon, Ref. No. 237/7 June 29 th 1939, TNA 25777.

${ }^{66}$ Seimu, S.M.L, The Growth and Development of the Coffee and Cotton Marketing Co-operative Movement in Tanzania, 1932-1982, Unpublished PhD Thesis, University of Central Lancashire, 2015.

67 Session a Paper No. 4, 1937, p.9; KNCU School Lyamungo, TNA 5/375C 24/13; Memorandum of Disturbances in the Moshi District, pp. 208 - 209, TNA 25400; Government of Tanganyika, Annual Report, Northern Province. (Dar Es Salaam: Government Printer, 1937), pp. 9 - 10.

${ }^{68}$ Seimu, S.M.L, The Growth and Development of the Coffee and Cotton Marketing Co-operative Movement in Tanzania, 1932-1982, Unpublished PhD Thesis, University of Central Lancashire, 2015.

${ }^{69}$ Extract from Lord Winster in his speech March 1, 2 or 3 to the House of Lords, TNA 357883.

${ }^{70}$ Extract from Lord Winster in his speech March 1, 2 or 3 to the House of Lords, TNA 357883.

${ }^{71}$ Tanganyika Territory, LEGCO, A report on the Kilimanjaro Native Co-operative Union, (Dar Es Sa salaam: Government Printer, 1937), pp. 9 -10, TNA 19005.

${ }^{72}$ DO to Mangi of Mwika Abdiel Solomon, Ref. No. 237/7 June 29 th 1939, TNA 25777.

${ }^{73}$ Mangi of Mwika, Abdiel Solomon to DO, Ref. No. L. 9/6/39 July 14 ${ }^{\text {th }}$ 1939, TNA 25777.

${ }^{74}$ Mangi of Mwika, Abdiel Solomon to DO, Ref. No. L. 9/6/39 July 14 ${ }^{\text {th }} 1939$, TNA 25777.

75 CS to PC, Northen Province, December 21 ${ }^{\text {st }}$ 1937, TNA 25442; Tanganyika Territory, LEGCO, A report on the Kilimanjaro Native Co-operative Union, (Dar Es Salaam, Government Printer, 1937), p.41, TNA 19005.

${ }^{76}$ CS to Secretary of the Colonies, February $7^{\text {th }} 1938$, TNA 25038 Legislation to Control Native Agriculture and Industry.

${ }^{77}$ Coffee Ordinance and Regulations: Attitude of the KNPA in Report on the Reorganisation of the KNPA, TNA 13060.

${ }^{78}$ Secretariat to PC, Northern Province, Ref. No. 25442/30, December $22^{\text {nd }} 1937$, TNA 25442.

${ }^{79}$ Secretariat to PC, Northern Province, Ref. No. 25442/30, December 22 ${ }^{\text {nd }} 1937$, TNA 25442.

${ }^{80}$ F.C. Hallier, Northern Province PC to CS, Ref. No 377/7/96, December 28 ${ }^{\text {th }}$ 1937, TNA 25442

${ }^{81}$ F.C. Hallier, Northern Province PC to CS, Ref. No 377/7/96, December $28^{\text {th }} 1937$, TNA 25442

${ }^{82}$ Northern Province, PC to CS, Confidential, Ref. No. 377/7/96, December $28^{\text {th }} 1937$, TNA 25442.

${ }^{83}$ PC, Northern Province to CS, Confidential, Ref. No. 377/7/96, December $28^{\text {th }}$ 1937, TNA 25442.

84 Somo M.L. Seimu, "Coffee and Cotton Bulk Purchase In Tanzania, 1939 - 1954”, International Journal of Research - Granthaalayah, Vol. 4, No. 4 (2016);

85 The Long Term Contracts Policy on the United Kingdom Departments and Colonial Agriculture Producer, TNA 25147; Standard Newspaper September 28 $8^{\text {th }} 1948$, TNA 25147.

${ }^{86}$ A Contract on the Local Arrangement for Handing of Ministry of Food Coffee, Director of East Africa Produce Disposal and Supply Council (Nairobi), March 13 ${ }^{\text {th }} 1947$, TNA 37200.

${ }^{87}$ East Africa High Commission, London to East Africa Joint Economic Commission (Nairobi) Confidential Telegram, Ref. No. 4142/458, October 28 th 1949, TNA 37200. 
${ }^{88}$ KNCU to Ministry of Food, TNA 37200.

${ }^{89}$ Extract from minute of meeting of the standing committee held in April 1947, TNA 11969.

${ }^{90}$ KNCU to Ministry of Food, TNA 37200.

${ }^{91}$ Tanganyika Legislative Council Debates, Hansard, 1950, $29^{\text {th }}$ Session, para. 241, TNA 37200.

${ }^{92}$ The Decontrol of Coffee, Press Notice by Ministry of Food August 20 $0^{\text {th }}$ 1952, TNA 37200.

${ }^{93}$ The Decontrol of Coffee, Press Notice by Ministry of Food August 20 $0^{\text {th }}$ 1952, TNA 37200.

94 USDA, United Kingdom Market for United States Agricultural Products Agriculture Information Bulletin No. 104, (Washington, D. C.: The USA Government Printing Office, 1953), p.56.

${ }^{95}$ Seimu, S.M.L, The Growth and Development of the Coffee and Cotton Marketing Co-operative Movement in Tanzania, 1932-1982, Unpublished PhD Thesis, University of Central Lancashire, 2015.

${ }^{96}$ Seimu, S.M.L, The Growth and Development of the Coffee and Cotton Marketing Co-operative Movement in Tanzania, 1932-1982, Unpublished PhD Thesis, University of Central Lancashire, 2015. 